\title{
Ornithinibacillus gen. nov., with the species Ornithinibacillus bavariensis sp. nov. and Ornithinibacillus californiensis sp. nov.
}

\author{
Correspondence \\ S. Scherer \\ siegfried.scherer@wzw.tum.de
}

\author{
R. Mayr, ${ }^{1}$ H.-J. Busse, ${ }^{2}$ H. L. Worliczek, ${ }^{2}$ M. Ehling-Schulz ${ }^{1}$ and S. Scherer ${ }^{1}$ \\ ${ }^{1}$ Lehrstuhl für Mikrobielle Ökologie, Department für Grundlagen der Biowissenschaften, WZW, \\ Technische Universität München, D-85354 Freising, Germany \\ ${ }^{2}$ Institut für Bakteriologie, Mykologie und Hygiene, Veterinärmedizinische Universität, A-1210 \\ Wien, Austria
}

A Gram-positive, aerobic, rod-shaped, motile, endospore-forming bacterium was isolated from pasteurized milk from Bavaria, Germany. 16S rRNA gene sequence similarities indicated that strain WSBC $24001^{\top}$ was most closely related to Virgibacillus species (95.3-96.1\%), Oceanobacillus species (95.6-95.7\%), Bacillus firmus IAM $12464^{\top}(95 \cdot 5 \%)$ and Bacillus niacini IFO $15566^{\top}$ (95.2\%). However, strain WSBC $24001^{\top}$ showed the highest level of sequence similarity to an unnamed strain, MB-9 ${ }^{\top}(97 \cdot 6 \%)$, which was isolated from coastal surface sediments in California. Hence, this strain was included in our study. The genomic DNA G + C contents of strains WSBC $24001^{\top}$ and $M B-9^{\top}$ were $36 \cdot 4 \mathrm{~mol}$ and $40 \cdot 8 \mathrm{~mol} \%$, respectively. The major respiratory quinone of both strains was menaquinone MK-7 and the peptidoglycan type was $A 4 \beta$ (L-Orn $\leftarrow D-A s p$ ). The polar lipid profiles of these strains contained a predominance of diphosphatidylglycerol and moderate to minor amounts of phosphatidylglycerol, an unknown phospholipid and an unknown aminophospholipid. However, strain WSBC $24001^{\top}$ could be distinguished from strain MB $-9^{\top}$ by the presence of an unknown lipid. The fatty acid profiles of the two strains comprised mainly iso- and anteiso-branched acids, but showed some significant quantitative differences in the amounts of certain acids. The DNA-DNA relatedness value $(15.5 \%)$ clearly demonstrated that strains WSBC $24001^{\top}$ and $M B-9^{\top}$ are representatives of two different species. On the basis of their phylogenetic position and morphological, physiological and chemotaxonomic properties, a novel genus is proposed, Ornithinibacillus gen. nov., with two novel species, the type species Ornithinibacillus bavariensis sp. nov. (type strain WSBC $24001^{\top}=\mathrm{DSM} 15681^{\top}=\mathrm{CCM} 7096^{\top}$ ) and Ornithinibacillus californiensis sp. nov. (type strain $\mathrm{MB}-9^{\top}=\mathrm{DSM} 16628^{\top}=\mathrm{CCM}^{\top} 237^{\top}$ ).
Aerobic endospore-forming bacteria represent an obligate and well-known part of the microbiota of pasteurized milk, which has been studied extensively over decades. Nevertheless, analysis of the microbiota of commercial hightemperature, short-time (HTST) pasteurized milk from a Bavarian dairy revealed the presence of an endosporeforming bacterium, designated as strain WSBC $24001^{\mathrm{T}}$, that could not be identified as a member of a species with a validly published name. 16S rRNA gene sequence analysis revealed a close relationship between strain WSBC $24001^{\mathrm{T}}$ and strain $\mathrm{MB}-9^{\mathrm{T}}$, which was isolated from coastal surface sediments in California (Francis \& Tebo, 2002). The two strains were studied in detail to find a taxonomic home for

Abbreviation: HTST, high-temperature, short-time.

The GenBank/EMBL/DDBJ accession number for the 16S rRNA gene sequence of strain WSBC $24001^{\top}$ is $Y 13066$. these closely related organisms isolated from two such different environments.

A retail sample of Bavarian HTST pasteurized $\left(72{ }^{\circ} \mathrm{C}, 30 \mathrm{~s}\right)$ milk was plated on plate-count agar containing $\left(1^{-1}\right) 5 \cdot 0 \mathrm{~g}$ casein peptone (Oxoid), $2 \cdot 5 \mathrm{~g}$ yeast extract (bioMérieux), $1.0 \mathrm{~g}$ glucose and $15 \mathrm{~g}$ agar agar, $\mathrm{pH} 7 \cdot 0$. Strain WSBC $24001^{\mathrm{T}}$ was isolated from plates incubated aerobically at $30{ }^{\circ} \mathrm{C}$ for $72 \mathrm{~h}$. The isolate lost its viability during repeated subcultivation on plate-count agar, but grew well within 3 days at $30{ }^{\circ} \mathrm{C}$ on modified trypticase soy agar (TSA) containing $\left(1^{-1}\right) 17 \cdot 0 \mathrm{~g}$ casein peptone (Oxoid), 3.0 g phytone peptone (Becton Dickinson), $5 \mathrm{~g} \mathrm{NaCl}, 2.5 \mathrm{~g} \mathrm{~K}_{2} \mathrm{HPO}_{4}$, 2.5 g glucose, 6 g yeast extract (bioMérieux) and $15 \mathrm{~g}$ agar, $\mathrm{pH} 7 \cdot 3$. Strain MB- $9^{\mathrm{T}}$ was isolated by Francis \& Tebo (2002) from surface sediment samples collected at the waterline from the shore of Mission Bay (San Diego, CA, USA) during low tide; sediment samples were diluted in seawater, 
incubated at $80{ }^{\circ} \mathrm{C}$ for $10 \mathrm{~min}$ and then plated on $\mathrm{Mn}$ (II)containing $\mathrm{K}$ agar (Francis \& Tebo, 2002).

$16 \mathrm{~S}$ rRNA gene sequence analysis was performed as described previously (Lechner et al., 1998). Sequence comparisons were done using FASTA3 (Pearson \& Lipman, 1988). Strain WSBC $24001^{\mathrm{T}}$ showed highest levels of 16S rRNA gene sequence similarity $(97 \cdot 6$ and $97 \cdot 3 \%$, respectively) to strain MB- $9^{\mathrm{T}}$ (GenBank accession no. AF326365) and strain AS-39 (GenBank accession no. AJ391200), a marine bacterium isolated from the Adriatic Sea. For strains WSBC $24001^{\mathrm{T}}$ and MB- $9^{\mathrm{T}}$, sequence similarities indicated that the most closely related established taxa with validly published names were species of the genera Virgibacillus $(94 \cdot 6-96 \cdot 1 \%)$ and Oceanobacillus $(94 \cdot 7-95 \cdot 7 \%)$, Bacillus firmus IAM $12464^{\mathrm{T}}$ (95.5 and $93.6 \%$, respectively) and Bacillus niacini IFO $15566^{\mathrm{T}}(95 \cdot 2$ and $94 \cdot 0 \%$, respectively). Sequences were aligned and manually edited using CLUSTAL X (Thompson et al., 1997) and BioEdit (Hall, 1999). The phylogenetic position of strain WSBC $24001^{\mathrm{T}}$ was calculated using software included in the PHYLIP package (Felsenstein, 1993). Sequence distances were calculated on the basis of Kimura's two-parameter model (Kimura, 1980). In all of the phylogenetic trees constructed using neighbour joining (Fig. 1), maximum likelihood and maximum parsimony (not shown), strain WSBC $24001^{\mathrm{T}}$ was most closely related to the unnamed strain $\mathrm{MB}-9^{\mathrm{T}}$ and more distantly to Oceanobacillus species.

Whilst strain AS-39 was not accessible, strain MB- $9^{\mathrm{T}}$ was kindly provided by Bradley M. Tebo (Scripps Institute of
Oceanography, San Diego, USA) and thus we could include it in our studies.

Cell morphology and spore formation were examined using a Laborlux S microscope (Leitz). On TSA, the frequency of endospores was low. However, spore formation could usually be observed after 10 days at $30^{\circ} \mathrm{C}$. Motility was tested by spot-inoculation of a plate with trypticase soy soft agar $(0 \cdot 4 \%$ agar agar) supplemented with $3 \% \mathrm{NaCl}(\mathrm{w} / \mathrm{v})$. After incubation for 3 days at $30^{\circ} \mathrm{C}$, motility was manifested macroscopically as a diffuse zone of growth spreading from the point of inoculation. Swimming motility was observed under the microscope. Morphological characteristics are given in the species description.

Under anaerobic conditions using Anaerocult A (Merck) in an anaerobic jar (Oxoid), no growth was observed for strain WSBC $24001^{\mathrm{T}}$ or strain MB- $9^{\mathrm{T}}$ after 7 days on TSA at $30{ }^{\circ} \mathrm{C}$. When trypticase soy soft agar $(0.4 \%$ agar agar $)$ was prepared in a tube and inoculated by stabbing through the centre of the medium with an inoculation needle, growth was observed only in the upper $1 \mathrm{~mm}$ after 7 days at $30^{\circ} \mathrm{C}$. Growth tests were performed in trypticase soy broth (TSB) and TSB supplemented with $3 \% \mathrm{NaCl}$ on a rotary shaker at 170 r.p.m. Growth was determined by monitoring the optical density at $585 \mathrm{~nm}$ with a portable WinLab photometer LF2400 (Windaus Labortechnik) after 1, 2, 7, 14, 21 and 28 days incubation at various temperatures. Growth was defined as an increase of at least $0 \cdot 1$ optical density units. The growth profile of WSBC $24001^{\mathrm{T}}$ differed significantly from that of MB-9 ${ }^{\mathrm{T}}$. Generally, WSBC $24001^{\mathrm{T}}$

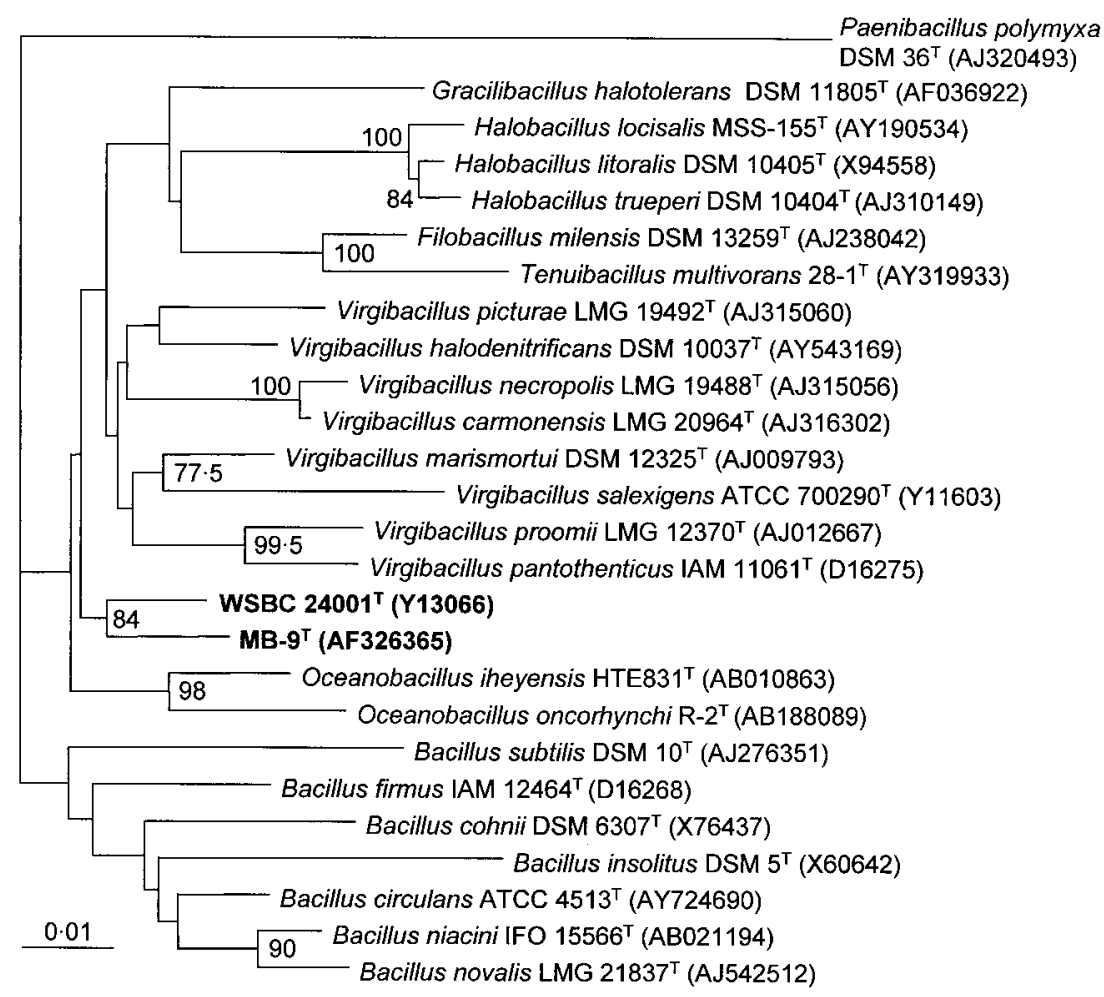

Fig. 1. Distance-matrix tree clustered by neighbour joining based on 16S rRNA gene sequences showing the position of strains WSBC $24001^{\top}$ and $\mathrm{MB}-9^{\top}$ among phylogenetic neighbours of the genera Bacillus, Oceanobacillus, Virgibacillus, Halobacillus, Filobacillus, Tenuibacillus and Gracilibacillus. Paenibacillus polymyxa DSM $36^{\top}$ was used as an outgroup. Bootstrap percentages (from 200 replications) greater than $70 \%$ are shown at branching points. Bar, 0.01 substitutions per nucleotide position. 
showed better growth than MB- $9^{\mathrm{T}}$ at temperatures $\geqslant 37^{\circ} \mathrm{C}$, whereas MB- $9^{\mathrm{T}}$ showed better growth than WSBC $24001^{\mathrm{T}}$ at temperatures $\leqslant 30{ }^{\circ} \mathrm{C}$. The $\mathrm{pH}$ range for growth was determined on PYE agar adjusted to $\mathrm{pH} 5,6,7,8,9$ and 10 by the addition of $\mathrm{HCl}$ or $\mathrm{NaOH}$; growth was monitored for 10 days. Growth at various $\mathrm{NaCl}$ concentrations was tested on PYE agar (Hauser et al., 2004) supplemented with 0, 0.5, $2,4,6,8,10,12,14$ and $16 \% \mathrm{NaCl}(\mathrm{w} / \mathrm{v})$.

Catalase was tested with $3 \% \mathrm{H}_{2} \mathrm{O}_{2}$ and oxidase was tested with ready-to-use test strips (Merck). Gram-behaviour was tested by staining cells grown on TSA for 2 and 18 days and by means of the $\mathrm{KOH}$ test and L-alanine aminopeptidase activity (Moaledj, 1986). Acid production from carbohydrates was examined over a period of 6 weeks using the API $50 \mathrm{CHB}$ system according to the instructions of the manufacturer (bioMérieux), but covering of the tubes with paraffin oil was necessary to obtain reproducible results.

No clearly reproducible results could be obtained for the two strains with the API $50 \mathrm{CH}$ system and AUX inoculation medium (bioMérieux), but aesculin hydrolysis tested as positive for WSBC $24001^{\mathrm{T}}$ and MB-9 ${ }^{\mathrm{T}}$. The API 20E system was applied as recommended by the manufacturer (bioMérieux). Biolog GP2 microplates were also used. For strain WSBC $24001^{\mathrm{T}}$, the microplates were used according to the manufacturer's instructions without modification; for strain MB- $9^{\mathrm{T}}$, the medium was adjusted to $3 \%(\mathrm{w} / \mathrm{v}) \mathrm{NaCl}$. Microplates were incubated for $48 \mathrm{~h}$ at $28^{\circ} \mathrm{C}$. Lecithinase activity was tested on TSA supplemented with $3 \% \mathrm{NaCl}$ and egg-yolk emulsion (Oxoid) at $50 \mathrm{ml} \mathrm{l}^{-1}$. Formation of dihydroxyacetone was investigated on glycerol/J agar (Claus \& Berkeley, 1986) supplemented with $12 \cdot 0 \mathrm{~g}$ casein peptone $1^{-1}, 3 \cdot 0$ g phytone peptone $l^{-1}$ and $30 \cdot 0 \mathrm{~g} \mathrm{NaCl}^{-1}$, and the ability to hydrolyse starch was tested as described by Claus \& Berkeley (1986). Haemolysis was assessed by spot-inoculation on TSA supplemented with $5 \%$ ovine blood (Oxoid) followed by incubation at $37^{\circ} \mathrm{C}$ for $1-3$ days.

The fatty acid profiles were analysed at the Identification Service of the Deutsche Sammlung von Mikroorganismen und Zellkulturen (DSMZ, Braunschweig, Germany) as described by Kämpfer \& Kroppenstedt (1996) and are listed in the species descriptions below. The fatty acid profiles of WSBC $24001^{\mathrm{T}}$ and MB- ${ }^{\mathrm{T}}$ contained a predominance of branched acids of the iso and anteiso types $(>80 \%)$. The two strains were distinguishable by the significant differences in the content of $\mathrm{C}_{16: 0}$, iso- $\mathrm{C}_{16: 0}$ and iso- $\mathrm{C}_{14: 0}$.

Quinones were extracted and analysed according to Tindall (1990) and Altenburger et al. (1996). Strain WSBC 24001 ${ }^{\mathrm{T}}$ contained a quinone system that consisted of the major compound MK-7 (98\%) and the minor compound MK-8 $(2 \%)$. In strain $\mathrm{MB}-9^{\mathrm{T}}$, the quinone system consisted exclusively of MK-7. These quinone systems are consistent with those found in numerous aerobic, endospore-forming bacteria, including members of the genera Virgibacillus (Heyrman et al., 2003) and Oceanobacillus (Lu et al., 2001; Yumoto et al., 2005). Polar lipids of WSBC $24001^{\mathrm{T}}$, MB-9 ${ }^{\mathrm{T}}$ and Oceanobacillus iheyensis DSM $14371^{\mathrm{T}}$ were analysed according to Tindall (1990). Highly similar polar lipid profiles were detected in WSBC $24001^{\mathrm{T}}$ (Fig. 2a) and MB-9 ${ }^{\mathrm{T}}$ (results not shown). Both strains contained the predominant compound diphosphatidylglycerol, minor amounts of phosphatidylglycerol and an unknown phosphatecontaining lipid, PL10. Additionally, minor amounts of an unknown aminophospholipid, APL1, and an unknown
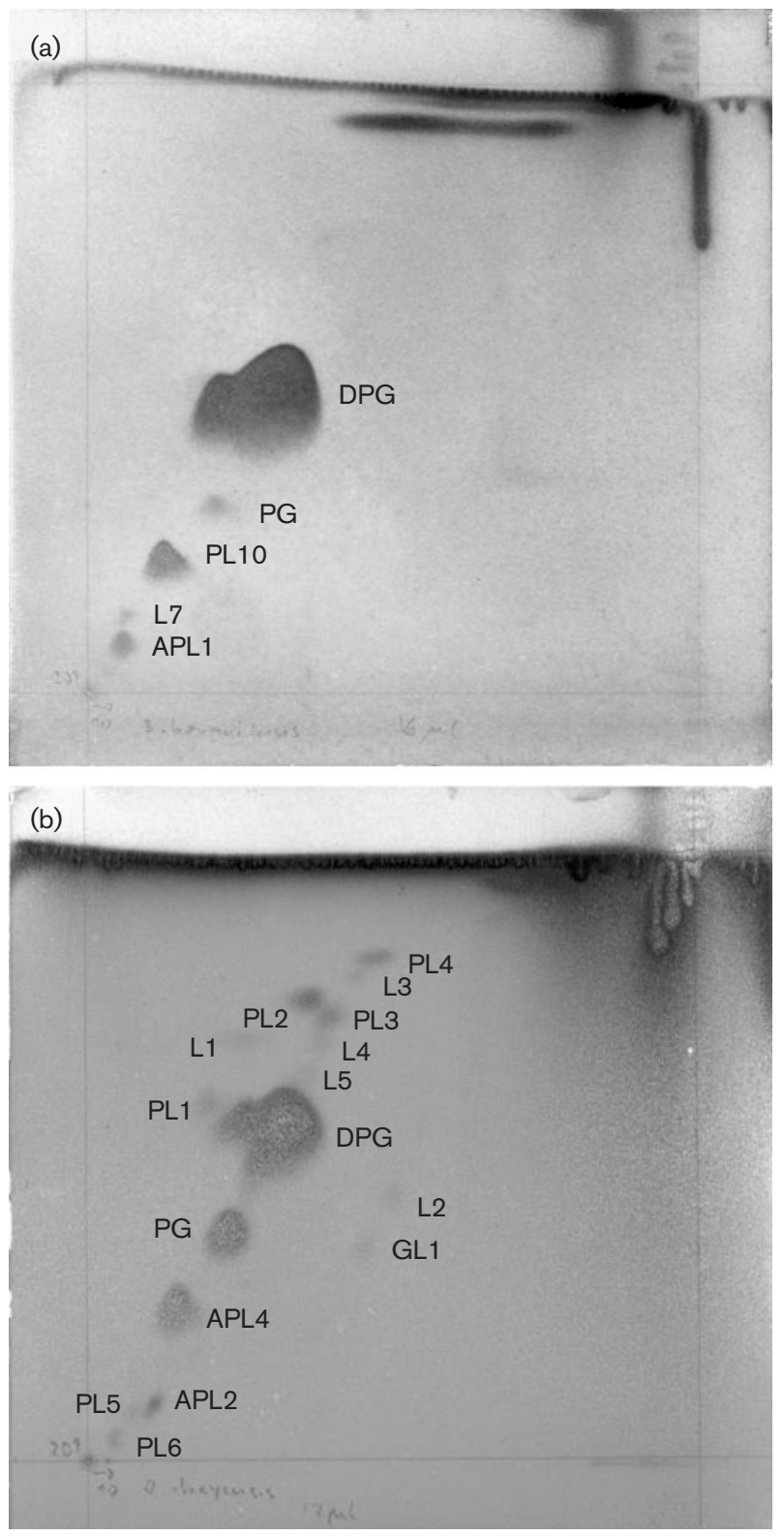

Fig. 2. Two-dimensional thin-layer chromatograms of polar lipids of Ornithinibacillus bavariensis WSBC $24001^{\top}$ (a) and Oceanobacillus iheyensis DSM $14371^{\top}$ (b). Abbreviations: DPG, diphosphatidylglycerol; PG, phosphatidylglycerol; PL1-6 and PL10, unknown phospholipids; APL1, APL2 and APL4, unknown aminophospholipids; GL1, unknown glycolipid; L1-5 and L7, unknown lipids. 
lipid, L7, were detected in WSBC $24001^{\mathrm{T}}$ and trace amounts of an aminolipid were found in $\mathrm{MB}-9^{\mathrm{T}}$. Although Oceanobacillus iheyensis DSM $14371^{\mathrm{T}}$ contained diphosphatidylglycerol and phosphatidylglycerol like the other two strains, it could be readily distinguished by the more complex profile, additionally consisting of six unknown phospholipids, two unknown aminophospholipids and an unknown glycolipid (Fig. 2b). The polar lipid profile also distinguished WSBC $24001^{\mathrm{T}}$ and MB- $9^{\mathrm{T}}$ from Virgibacillus species (Heyrman et al., 2003). Their profiles were less complex and phosphatidylglycerol was detected only in minor amounts, whereas it was reported to be present in moderate to major amounts in Virgibacillus species.

Analysis of the cell-wall composition of WSBC $24001^{\mathrm{T}}$ and MB- $9^{\mathrm{T}}$ was carried out by the DSMZ as described by Schleifer \& Kandler (1972), Schleifer (1985), MacKenzie (1987) and Groth et al. (1996). Gas chromatographic analysis of derivatized amino acids indicated Ala/Asp/Orn/ Glu molar ratios of $2 \cdot 1: 1 \cdot 2: 1 \cdot 0: 1 \cdot 6$ for WSBC $24001^{\mathrm{T}}$ and $2 \cdot 7: 0 \cdot 9: 1 \cdot 0: 1 \cdot 9$ for $\mathrm{MB}-9^{\mathrm{T}}$ (additionally, traces of lysine were detected). On the basis of the presence of Asp $\rightarrow$ Orn and $\mathrm{L}-\mathrm{Ala} \rightarrow \mathrm{D}-\mathrm{Glu}$, it was concluded that peptidoglycan type $\mathrm{A} 4 \beta$ (L-Orn $\leftarrow \mathrm{D}-\mathrm{Asp}$ ) was present. In contrast, Oceanobacillus iheyensis DSM $14371^{\mathrm{T}}$ and Virgibacillus picturae DSM $14867^{\mathrm{T}}$, which were also analysed, had the same peptidoglycan type, $\mathrm{A} 1 \gamma$ (meso-diaminopimelic acid direct) (Table 1). The latter type is found in the majority of endospore-forming rod-shaped bacteria; a murein type based on L-ornithine is somewhat unusual for this group of bacteria, though it has been described for members of the genera Halobacillus (Amoozegar et al., 2003) and Filobacillus (Schlesner et al., 2001), genera that are distantly related to $\mathrm{MB}-9^{\mathrm{T}}$ and $\mathrm{WSBC} 24001^{\mathrm{T}}$. Other characteristics that differentiate WSBC $24001^{\mathrm{T}}$ and $\mathrm{MB}-9^{\mathrm{T}}$ from related species are given in Table 1.
Extraction of DNA (Cashion et al., 1977), determination of the $\mathrm{G}+\mathrm{C}$ content by HPLC (Tamaoka \& Komagata, 1984; Mesbah et al., 1989) and spectrophotometric DNA-DNA hybridization (De Ley et al., 1970; Huß et al., 1983; Escara \& Hutton, 1980) were carried out by the Identification Service of the DSMZ. Renaturation rates were computed with the TRANSFER.BAS program (Jahnke, 1992). The G + C content of the genomic DNA of WSBC $24001^{\mathrm{T}}$ and $\mathrm{MB}-9^{\mathrm{T}}$ was determined to be 36.4 and $40.8 \mathrm{~mol} \%$, respectively. Genomic DNA of strains WSBC $24001^{\mathrm{T}}$ and $\mathrm{MB}-9^{\mathrm{T}}$ revealed DNA-DNA relatedness of $15 \cdot 5 \%$. This result clearly demonstrates that strains WSBC $24001^{\mathrm{T}}$ and $\mathrm{MB}-9^{\mathrm{T}}$ are representatives of two distinct species.

The phylogenetic analyses of WSBC $24001^{\mathrm{T}}$ and MB-9 ${ }^{\mathrm{T}}$ and $16 \mathrm{~S}$ rRNA gene sequence similarities indicate that these two strains may be neighbours of the genera Virgibacillus and Oceanobacillus (Fig. 1). However, there is no statistical support for the branching (bootstrap values of 45 and $20 \%$, respectively). The two strains have the same peptidoglycan type and they have very similar polar lipid profiles, both features that distinguish them from related taxa (Table 1). Their degree of DNA-DNA relatedness demonstrates unambiguously that strains WSBC $24001^{\mathrm{T}}$ and $\mathrm{MB}-9^{\mathrm{T}}$ are members of separate species. These data suggest that they should be classified as separate species in a novel genus, for which we propose the name Ornithinibacillus, with Ornithinibacillus bavariensis and Ornithinibacillus californiensis as the two species.

\section{Description of Ornithinibacillus gen. nov.}

Ornithinibacillus (Or'ni.thi.ni.ba.cil'lus. N.L. n. ornithina ornithine; L. masc. n. bacillus a small staff, a wand; N.L. masc. n. Ornithinibacillus a rod with ornithine).

Table 1. Characteristics useful for differentiation of strains $\mathrm{WSBC} 24001^{\top}$ and $M B-9^{\top}$ (Ornithinibacillus gen. nov.) from the genera Oceanobacillus, Virgibacillus and Halobacillus

Symbols: +, present; -, absent; V, variable; ND, not determined; DAP, diaminopimelic acid. Unless indicated otherwise, data for Virgibacillus were taken from Heyrman et al. (2003) and Yoon et al. (2004) and data for Halobacillus were taken from Amoozegar et al. (2003).

\begin{tabular}{|c|c|c|c|c|}
\hline Characteristic & Ornithinibacillus & Oceanobacillus & Virgibacillus & Halobacillus \\
\hline iso- $C_{15: 0}$ /anteiso- $C_{15: 0}$ ratio & $>1$ & $<1$ & $0 \cdot 05-1 \cdot 7$ & $0 \cdot 2-0 \cdot 4$ \\
\hline Peptidoglycan type & $\mathrm{A} 4 \beta(\mathrm{L}-\mathrm{Orn} \leftarrow \mathrm{D}-\mathrm{Asp})$ & $\mathrm{A} 1 \gamma(\text { meso-DAP direct })^{*}$ & $\mathrm{~A} 1 \gamma(\text { meso-DAP direct })^{*}$ & $\mathrm{~A} 4 \beta(\mathrm{L}-\mathrm{Orn} \leftarrow \mathrm{D}-\mathrm{Asp})$ \\
\hline Phosphatidylglycerol content & Minor & Moderate & Moderate to major & Present $^{a} \dagger$ \\
\hline Upper limit of $\mathrm{NaCl}$ tolerance $(\%, \mathrm{w} / \mathrm{v})$ & $10-12$ & $>20$ & $>10-25$ & $>20-30$ \\
\hline Growth temperature range $\left({ }^{\circ} \mathrm{C}\right)$ & $10-45$ & $15-42^{b}$ & $5-50$ & $10-49$ \\
\hline \multicolumn{5}{|l|}{ Acid production from: } \\
\hline D-Mannose & - & $+{ }^{b}$ & $\mathrm{~V}$ & + \\
\hline D-Trehalose & + & $-{ }^{b}$ & $\mathrm{~V}$ & ND \\
\hline DNA G $+C$ content $(\mathrm{mol} \%)$ & $36-41$ & $36^{b}$ & $36-42$ & $40-43$ \\
\hline
\end{tabular}

${ }^{*}$ Determined in this study for Oceanobacillus iheyensis and V. picturae. Virgibacillus pantothenticus contains meso-diaminopimelic acid direct (Claus \& Berkeley, 1986) and Virgibacillus halodenitrificans and Virgibacillus salexigens contain meso-diaminopimelic acid (Yoon et al., 2004). $\dagger$ Data taken from: $a$, Wainø et al. (1999); b, Lu et al. (2001). 
Halotolerant to moderately halophilic. The characteristic diamino acid in the cell wall is ornithine and the peptidoglycan type is $A 4 \beta$ (L-Orn $\leftarrow D-A s p)$. Cellular fatty acids consist mainly of iso- and anteiso-branched acids, with iso$\mathrm{C}_{15: 0}$ and anteiso- $\mathrm{C}_{15: 0}$ predominating and moderate amounts of iso- $\mathrm{C}_{16: 0}$ and anteiso- $\mathrm{C}_{17: 0}$. The predominant compound in the polar lipid profile is diphosphatidylglycerol; moderate to minor amounts of an unknown phospholipid, an unknown aminophospholipid and phosphatidylglycerol are present. Menaquinone MK-7 is the predominant respiratory quinone. The DNA G $+\mathrm{C}$ content is 36-41 mol\%. The type species is Ornithinibacillus bavariensis.

\section{Description of Ornithinibacillus bavariensis sp. nov.}

Ornithinibacillus bavariensis (ba.va.ri.en'sis. N.L. masc. adj. bavariensis of Bavaria, indicating the source of the type strain).

Cells are regular, motile rods, $0 \cdot 4 \mu \mathrm{m}$ wide and $2-6 \mu \mathrm{m}$ long, which occur singly or sometimes in short chains. Gram-behaviour of vegetative cells is positive with staining and in the $\mathrm{KOH}$ and aminopeptidase tests. Because of the presence of an oval spore in a terminal position, the swollen sporangium (width approx. $0 \cdot 8 \mu \mathrm{m}$ ) appears racket-shaped. On TSA, the type strain grows strictly aerobically, forming round, raised, slightly brownish/orange colonies with small regular margins. Within 10 days at $30^{\circ} \mathrm{C}$, the diameter of a single colony reaches about $10 \mathrm{~mm}$. Halotolerant on PYE agar. Growth occurs with $\mathrm{NaCl}$ at $0-10 \%(w / v)$, with a growth optimum at $0.5-4 \%$. Growth occurs at 15 and $45^{\circ} \mathrm{C}$, but not at $7{ }^{\circ} \mathrm{C}$. Optimal growth is observed at $42{ }^{\circ} \mathrm{C}$. Grows occurs at $\mathrm{pH} 7-10$ on PYE agar but not at $\mathrm{pH}$ 6. Catalase-, oxidase- and gelatinase-positive. Results for acid production from carbohydrates (API $50 \mathrm{CHB}$ ) within 6 weeks and from Biolog GP2 testing are summarized in Table 2. Tests for $\beta$-galactosidase, arginine dihydrolase, lysine decarboxylase, ornithine decarboxylase, L-alanine aminopeptidase, $\mathrm{H}_{2} \mathrm{~S}$ production, urease, tryptophan deaminase, production of indole, production of acetoin, citrate utilization, nitrate reduction (API 20E), egg-yolk lecithinase, starch hydrolysis and formation of dihydroxyacetone are negative. Haemolysis is observed after incubation for 2 days at $37^{\circ} \mathrm{C}$ on blood agar. The peptidoglycan type, quinone system and polar lipid profile are as given in the genus description, but, in addition, an unknown polar lipid is present that cannot be stained with any of the specific spray reagents. The cellular fatty acid profile consists of iso- $\mathrm{C}_{15: 0}(39 \cdot 0 \%)$, anteiso$\mathrm{C}_{15: 0}(19 \cdot 9 \%), \mathrm{C}_{16: 0}(8 \cdot 0 \%)$, anteiso- $\mathrm{C}_{17: 0}(7 \cdot 7 \%)$, iso$\mathrm{C}_{16: 0}(6 \cdot 7 \%)$, iso- $\mathrm{C}_{17: 0}(5 \cdot 7 \%)$, iso- $\mathrm{C}_{14: 0}(3 \cdot 8 \%)$, $\mathrm{C}_{16: 1} \omega 11 c \quad(2 \cdot 8 \%), \mathrm{C}_{14: 0} \quad(1 \cdot 4 \%), \mathrm{C}_{16: 1} \omega 7 c$ alcohol $(1 \cdot 3 \%), \mathrm{C}_{15: 0}(1 \cdot 1 \%)$, iso- $\mathrm{C}_{17: 1} \omega 10 c(1 \cdot 1 \%)$, iso- $\mathrm{C}_{13: 0}$ $(1.0 \%)$ and summed feature 4 (iso- $\mathrm{C}_{17: 1}$ and/or anteiso$\left.\mathrm{C}_{17: 1}\right)(0 \cdot 7 \%)$. The $\mathrm{G}+\mathrm{C}$ content of the genomic DNA is $36 \cdot 4 \mathrm{~mol} \%$, as determined by HPLC.

The type strain, WSBC $24001^{\mathrm{T}}\left(=\mathrm{DSM} 15681^{\mathrm{T}}=\mathrm{CCM} 7096^{\mathrm{T}}\right)$, was isolated from pasteurized milk from Bavaria, Germany.
Table 2. Physiological characteristics of strains WSBC $24001^{\top}$ and $\mathrm{MB}-9^{\top}$

API $50 \mathrm{CHB}$ results were followed for up to 6 weeks at $30^{\circ} \mathrm{C}$. Biolog GP2 microplates were incubated for $48 \mathrm{~h}$ at $28^{\circ} \mathrm{C}$ as described in the text. Characteristics are scored as follows: +, positive within 1-2 weeks; W, positive within 4-6 weeks (API 50 $\mathrm{CHB}$ ) or weak colour development after $72 \mathrm{~h}$ (Biolog GP2); ?, plain-coloured to light-orange-coloured test volumes representing unclear results (API $50 \mathrm{CHB}$ ); v, not reproducible (Biolog GP2); -, negative. The two strains tested positive for acid production (API $50 \mathrm{CHB}$ ) from glycerol, D-glucose, trehalose and 5-ketogluconate within 1-2 weeks and tested positive for salicin within 4-6 weeks; both showed positive reactions in the Biolog tests for acetic acid, $\alpha$-ketovaleric acid and pyruvic acid. The two strains tested negative for acid production (API $50 \mathrm{CHB}$ ) from erythritol, $\mathrm{D}$ - and L-arabinose, $\mathrm{D}$ - and L-xylose, adonitol, methyl $\beta$-D-xyloside, galactose, D-mannose, L-sorbose, rhamnose, dulcitol, inositol, sorbitol, methyl $\alpha$-D-mannoside, methyl $\alpha$-D-glucoside, amygdalin, arbutin, lactose, melibiose, melezitose, D-raffinose, glycogen, xylitol, $\beta$-gentiobiose, D-turanose, D-lyxose, D- and L-fucose, D- and L-arabitol, gluconate and 2-ketogluconate. Both strains were negative in the Biolog reactions for $\alpha$-cyclodextrin, mannan, $N$-acetyl-D-glucosamine, $N$-acetyl- $\beta$-D-mannosamine, L-arabinose, D-arabitol, D-cellobiose, L-fucose, D-galactose, D-galacturonic acid, gentiobiose, D-gluconic acid, $\alpha$-D-glucose, myo-inositol, $\alpha$-D-lactose, lactulose, maltose, maltotriose, D-mannitol, D-mannose, D-melezitose, D-melibiose, methyl $\alpha$-D-galactoside, methyl $\beta$-D-galactoside, 3-methyl D-glucose, methyl $\alpha$-D-glucoside, methyl $\beta$-D-glucoside, methyl $\alpha$-D-mannoside, palatinose, D-psicose, D-raffinose, L-rhamnose, D-ribose, sedoheptulosan, stachyose, sucrose, D-tagatose, turanose, xylitol, D-xylose, $\alpha$-hydroxybutyric acid, $\gamma$-hydroxybutyric acid, $p$-hydroxyphenylacetic acid, lactamide, D-lactic acid methyl ester, L-lactic acid, D-malic acid, succinamic acid, succinic acid, $\mathrm{N}$-acetyl-L-glutamic acid, L-alaninamide, D-alanine, L-asparagine, putrescine, 2,3-butanediol, adenosine, $2^{\prime}$-deoxyadenosine, inosine, thymidine, adenosine $5^{\prime}$-monophosphate, thymidine $5^{\prime}$-monophosphate, uridine $5^{\prime}$ monophosphate, D-fructose 6-phosphate, $\alpha$-D-glucose 1-phosphate and D-glucose 6-phosphate. Strain WSBC $24001^{\mathrm{T}}$ tested negative in the following Biolog reactions: $\beta$-cyclodextrin, dextrin, glycogen, inulin, Tween 80 , arbutin, salicin, D-trehalose, $\beta$-hydroxybutyric acid, $\alpha$-ketoglutaric acid, propionic acid, L-alanine, L-pyroglutamic acid, L-serine, uridine and DL- $\alpha$-glycerol phosphate. Strain MB- $9^{\mathrm{T}}$ tested negative for the following Biolog reactions: amygdalin, D-fructose, D-sorbitol, succinic acid monomethyl ester, L-alanyl glycine, L-glutamic acid and glycyl L-glutamic acid.

\begin{tabular}{|lcc|}
\hline Characteristic & WSBC 24001 $^{\mathbf{T}}$ & MB-9 $^{\mathbf{T}}$ \\
\hline Growth in 12\% NaCl & - & $\mathrm{W}$ \\
Growth at pH 5-6 & - & + \\
Growth on TSA & $\mathrm{W}$ & + \\
Acid formation (API 50 CHB) from: & & \\
$\quad$ Ribose & + & $\mathrm{W}$ \\
D-Fructose & + & $?$ \\
Mannitol & + & - \\
Cellobiose & + & - \\
Maltose & - & $\mathrm{W}$ \\
Sucrose & - & + \\
\hline
\end{tabular}


Table 2. cont.

\begin{tabular}{|lcc|}
\hline Characteristic & WSBC $^{24001}$ & MB-9 $^{\mathbf{T}}$ \\
\hline Inulin & - & $?$ \\
Starch & - & $\mathrm{W}$ \\
D-Tagatose & $?$ & $\mathrm{~W}$ \\
Biolog reactions & & \\
$\beta$-Hydroxybutyric acid & - & + \\
L-Malic acid & $\mathrm{W}$ & $\mathrm{V}$ \\
Pyruvic acid methyl ester & + & $\mathrm{V}$ \\
\hline
\end{tabular}

\section{Description of Ornithinibacillus californiensis sp. nov.}

Ornithinibacillus californiensis (ca.li.for.ni.en'sis. N.L. masc. adj. californiensis of California, indicating the source of the type strain).

Cells are regular, motile rods, $0 \cdot 4 \mu \mathrm{m}$ wide and 2-6 $\mu \mathrm{m}$ long. Gram-behaviour of vegetative cells is positive with staining and in the $\mathrm{KOH}$ and aminopeptidase tests. Because of the presence of an oval spore in a terminal position, the swollen sporangium (width approx. $0 \cdot 8 \mu \mathrm{m}$ ) appears racket-shaped. On TSA, the type strain grows strictly aerobically, forming round, raised, slightly brownish/orange colonies with small regular margins. Within 10 days at $30{ }^{\circ} \mathrm{C}$, the diameter of single colonies reaches about $5 \mathrm{~mm}$. Grows at 10 and $37^{\circ} \mathrm{C}$ but not at 7 or $42^{\circ} \mathrm{C}$. At $10^{\circ} \mathrm{C}$, growth is visible after an incubation period of 2 weeks. Optimal growth temperature is $30^{\circ} \mathrm{C}$. On PYE agar, growth occurs with $\mathrm{NaCl}$ at $0 \cdot 5-12 \%(\mathrm{w} / \mathrm{v})$, with best growth between $0 \cdot 5$ and $8 \%$. No growth occurs in the absence of $\mathrm{NaCl}$. Good growth is observed at $\mathrm{pH} 5-9$ and weak growth at $\mathrm{pH} 10$. Catalase-, oxidase- and gelatinase-positive. Results for acid production from carbohydrates (API $50 \mathrm{CHB}$ ) within 6 weeks and from Biolog testing are summarized in Table 2. Tests for $\beta$-galactosidase, arginine dihydrolase, lysine decarboxylase, ornithine decarboxylase, $\mathrm{H}_{2} \mathrm{~S}$ production, urease, tryptophan deaminase, indole production and acetoin production, citrate utilization, nitrate reduction, starch degradation, egg-yolk lecithinase and formation of dihydroxyacetone are negative. Haemolysis is observed after 3 days incubation on blood agar. The peptidoglycan type, quinone system and polar lipid profile are as given in the genus description. The cellular fatty acid profile consists of iso- $\mathrm{C}_{15: 0}(32 \cdot 8 \%)$, anteiso- $\mathrm{C}_{15: 0}(23.9 \%)$, iso- $\mathrm{C}_{16: 0}$ $(14 \cdot 7 \%)$, iso- $\mathrm{C}_{14: 0}(10 \cdot 2 \%)$, anteiso- $\mathrm{C}_{17: 0} \quad(5 \cdot 4 \%)$, $\mathrm{C}_{16: 1} \omega 7 c$ alcohol $(4 \cdot 8 \%), \mathrm{C}_{16: 0}(2 \cdot 8 \%), \quad$ iso- $\mathrm{C}_{17: 0}$ $(1 \cdot 9 \%), \mathrm{C}_{16: 1} \omega 11 c(0 \cdot 9 \%), \mathrm{C}_{14: 0}(0 \cdot 7 \%)$, summed feature 4 (iso- $\mathrm{C}_{17: 1}$ and/or anteiso- $\left.\mathrm{C}_{17: 1}\right)(0 \cdot 7 \%)$, iso- $\mathrm{C}_{13: 0}$ $(0 \cdot 6 \%)$ and $\mathrm{C}_{15: 0}(0 \cdot 6 \%)$. The $\mathrm{G}+\mathrm{C}$ content of the genomic DNA is $40 \cdot 8 \mathrm{~mol} \%$.

The type strain, MB- $9^{\mathrm{T}}\left(=\right.$ DSM $\left.16628^{\mathrm{T}}=\mathrm{CCM} 7237^{\mathrm{T}}\right)$, was isolated by Francis \& Tebo (2002) from sediments of Mission Bay, San Diego, CA, USA.

\section{Acknowledgements}

We wish to thank Sabine Lechner and Elke Wiesner-Gunkel for their work on the 16S rRNA gene sequence of strain WSBC $24001^{\mathrm{T}}$, as well as Bradley M. Tebo for supplying strain MB- ${ }^{\mathrm{T}}$. The technical assistance of Romy Renner is gratefully appreciated and we acknowledge the advice of J. Euzéby on nomenclature and etymology.

\section{References}

Altenburger, P., Kämpfer, P., Makristathis, A., Lubitz, W. \& Busse, H.-J. (1996). Classification of bacteria isolated from a medieval wall painting. J Biotechnol 47, 39-52.

Amoozegar, M. A., Malekzadeh, F., Malik, K. A., Schumann, P. \& Sproer, C. (2003). Halobacillus karajensis sp. nov., a novel moderate halophile. Int J Syst Evol Microbiol 53, 1059-1063.

Cashion, P., Holder-Franklin, M. A., McCully, J. \& Franklin, M. (1977). A rapid method for the base ratio determination of bacterial DNA. Anal Biochem 81, 461-466.

Claus, D. \& Berkeley, R. C. W. (1986). Genus Bacillus Cohn 1872. In Bergey's Manual of Systematic Bacteriology, vol. 2, pp. 1105-1140. Edited by P. H. A. Sneath, N. S. Mair, M. E. Sharpe \& J. G. Holt. Baltimore: Williams \& Wilkins.

De Ley, J., Cattoir, H. \& Reynaerts, A. (1970). The quantitative measurement of DNA hybridizations from renaturation rates. Eur J Biochem 12, 133-142.

Escara, J. F. \& Hutton, J. R. (1980). Thermal stability and renaturation of DNA in dimethyl sulfoxide solutions: acceleration of the renaturation rate. Biopolymers 19, 1315-1327.

Felsenstein, J. (1993). PHYLIP (phylogeny inference package), version 3.5c. Distributed by the author. Department of Genome Sciences, University of Washington, Seattle, USA.

Francis, C. A. \& Tebo, B. M. (2002). Enzymatic manganese(II) oxidation by metabolically dormant spores of diverse Bacillus species. Appl Environ Microbiol 68, 874-880.

Groth, I., Schumann, P., Weiss, N., Martin, K. \& Rainey, F. A. (1996). Agrococcus jenensis gen. nov., sp. nov., a new genus of actinomycetes with diaminobutyric acid in the cell wall. Int J Syst Bacteriol 46, 234-239.

Hall, T. A. (1999). BioEdit: a user-friendly biological sequence alignment editor and analysis program for Windows 95/98/NT. Nucleic Acids Symp Ser 41, 95-98.

Hauser, E., Kämpfer, P. \& Busse, H.-J. (2004). Pseudomonas psychrotolerans sp. nov. Int J Syst Evol Microbiol 54, 1633-1637.

Heyrman, J., Logan, N. A., Busse, H. J., Balcaen, A., Lebbe, L., Rodriguez-Diaz, M., Swings, J. \& De Vos, P. (2003). Virgibacillus carmonensis sp. nov., Virgibacillus necropolis sp. nov. and Virgibacillus picturae sp. nov., three novel species isolated from deteriorated mural paintings, transfer of the species of the genus Salibacillus to Virgibacillus, as Virgibacillus marismortui comb. nov. and Virgibacillus salexigens comb. nov., and emended description of the genus Virgibacillus. Int J Syst Evol Microbiol 53, 501-511.

Huß, V. A. R., Festl, H. \& Schleifer, K. H. (1983). Studies on the spectrophotometric determination of DNA hybridization from renaturation rates. Syst Appl Microbiol 4, 184-192.

Jahnke, K. D. (1992). Basic computer program for evaluation of spectroscopic DNA renaturation data from GILFORD System 2600 spectrometer on a PC/XT/AT type personal computer. J Microbiol Methods 15, 61-73.

Kämpfer, P. \& Kroppenstedt, R. M. (1996). Numerical analysis of fatty acid patterns of the coryneform bacteria and related taxa. Can J Microbiol 42, 989-1005. 
Kimura, M. (1980). A simple method for estimating evolutionary rates of base substitutions through comparative studies of nucleotide sequences. J Mol Evol 16, 111-120.

Lechner, S., Mayr, R., Francis, K. P., Prüß, B. M., Kaplan, T., Wießner-Gunkel, E., Stewart, G. S. A. B. \& Scherer, S. (1998). Bacillus weihenstephanensis sp. nov. is a new psychrotolerant species of the Bacillus cereus group. Int J Syst Bacteriol 48, 1373-1382.

Lu, J., Nogi, Y. \& Takami, H. (2001). Oceanobacillus iheyensis gen. nov., sp. nov., a deep-sea extremely halotolerant and alkaliphilic species isolated from a depth of $1050 \mathrm{~m}$ on the Iheya Ridge. FEMS Microbiol Lett 205, 291-297.

MacKenzie, S. L. (1987). Gas chromatographic analysis of amino acids as the $N$-heptafluorobutyryl isobutyl esters. J Assoc Off Anal Chem 70, 151-160.

Mesbah, M., Premachandran, U. \& Whitman, W. B. (1989). Precise measurement of the $\mathrm{G}+\mathrm{C}$ content of deoxyribonucleic acid by highperformance liquid chromatography. Int J Syst Bacteriol 39, 159-167.

Moaledj, K. (1986). Comparison of Gram-staining and alternate methods, $\mathrm{KOH}$ test and aminopeptidase activity in aquatic bacteria: their application to numerical taxonomy. J Microbiol Methods 5, 303-310.

Pearson, W. R. \& Lipman, D. J. (1988). Improved tools for biological sequence comparison. Proc Natl Acad Sci U S A 85, 2444-2448.

Schleifer, K. H. (1985). Analysis of the chemical composition and primary structure of murein. Methods Microbiol 18, 123-156.

Schleifer, K. H. \& Kandler, O. (1972). Peptidoglycan types of bacterial cell walls and their taxonomic implications. Bacteriol Rev 36, 407-477.
Schlesner, H., Lawson, P. A., Collins, M. D., Weiss, N., Wehmeyer, U., Völker, H. \& Thomm, M. (2001). Filobacillus milensis gen. nov., sp. nov., a new halophilic spore-forming bacterium with Orn-D-Glutype peptidoglycan. Int J Syst Evol Microbiol 51, 425-431.

Tamaoka, J. \& Komagata, K. (1984). Determination of DNA base composition by reversed-phase high-performance liquid chromatography. FEMS Microbiol Lett 25, 125-128.

Thompson, J. D., Gibson, T. J., Plewniak, F., Jeanmougin, F. \& Higgins, D. G. (1997). The CLUSTAL_X windows interface: flexible strategies for multiple sequence alignment aided by quality analysis tools. Nucleic Acids Res 25, 4876-4882.

Tindall, B. J. (1990). Lipid composition of Halobacterium lacusprofundi. FEMS Microbiol Lett 66, 199-202.

Wainø, M., Tindall, B. J., Schumann, P. \& Ingvorsen, K. (1999). Gracilibacillus gen. nov., with description of Gracilibacillus halotolerans gen. nov., sp. nov.; transfer of Bacillus dipsosauri to Gracilibacillus dipsosauri comb. nov., and Bacillus salexigens to the genus Salibacillus gen. nov., as Salibacillus salexigens comb. nov. Int J Syst Bacteriol 49, 821-831.

Yoon, J. H., Oh, T. K. \& Park, Y. H. (2004). Transfer of Bacillus halodenitrificans Denariaz et al. 1989 to the genus Virgibacillus as Virgibacillus halodenitrificans comb. nov. Int J Syst Evol Microbiol 54, 2163-2167.

Yumoto, I., Hirota, K., Nodasaka, Y. \& Nakajima, K. (2005). Oceanobacillus oncorhynchi sp. nov., a halotolerant obligate alkaliphile isolated from the skin of a rainbow trout (Oncorhynchus mykiss) and emended description of the genus Oceanobacillus. Int J Syst Evol Microbiol 55, 1521-1524. 